\title{
HODNOTENIE OBSAHU HUMUSU V PÔDE NA ZÁKLADE ENVIRONMENTÁLNYCH A EKOLOGICKÝCH FAKTOROV VO VYBRANÝCH ÚZEMIACH STREDNÉHO SLOVENSKA
}

\author{
Melánia Feszterová, Michal Hudec
}

\begin{abstract}
The importance of the potential evaluation and production capacity of soil lies in understanding the changes related to the content of humus in the soil. Environmental and ecological factors affect the process of humus creation in both a negative and a positive way. This process is affected by location, soil type, relief, season, climate, altitude and using of soil cover. The interaction of natural components with spatial fragmentation of the country has an important role in the cycle, modelling and sequestration of carbon stocks. The article summarizes the influence of land use and vegetation cover on the soil properties of different soil types and deals with the possibilities of using parametric tests in evaluation of humus content based on environmental and ecological factors. We investigated the differences in the values of humus on grass and forest ecosystem in Kremnické and Śtiavnické vrchy Mts. in identified soil types and in selected periods 2011-2014 years.
\end{abstract}

Keywords: Kremnické and Štiavnické vrchy Mts., landuse, season, total organic carbon, ecosystem

\section{Úvod}

Pôda, dôležitá zložka životného prostredia a ako súčast' geografického prostredia, umožňuje život rastlinám, živočíchom i človeku. Pôdotvorný substrát je jedným z faktorov, ktorý ovplyvňuje vývoj pôdy a jej úrodnost' (Turrión, Schneider, Gallardo, 2009). Kl'účový význam pre zhodnotenie potenciálu a produkčnej schopnosti pôdy predstavuje pochopenie zmien súvisiacich s obsahom humusu $\mathrm{v}$ pôde, $\mathrm{v}$ závislosti od environmentálnych a ekologických faktorov. Využitie krajiny v praxi môže mat' trvalý vplyv na distribúciu živín v pôde a môže zásadne ovplyvnit' obnovu prirodzeného ekosystému zmenou využitia pôdy (Fraterrigo et al., 2003, Aleksandrowicz-Trzcińska, 2005). Charakter prírodných prvkov a ich vlastnosti sa najvýraznejšie podiel'ajú na využití krajiny, čo má vplyv na kolobeh, sekvestráciu a modelovanie zásob uhlíka. Skúmanie vplyvu priestorovej diverzity krajiny, environmentálnych a ekologických a faktorov prostredia, pôdnych pomerov, ako aj časovej premenlivosti na obsah pôdneho uhlíka nepredstavuje len jeho stanovenie, ale významným je štatistické spracovanie a vyhodnotenie nameraných dát. 
Ciel'om príspevku je zhodnotit' vplyv environmentálnych a ekologických faktorov na obsah humusu v pôde v oblasti Kremnických vrchov a Štiavnických vrchov. Poukazuje na vybrané charakteristiky v pôdnych vzorkách a na dôležitost' parametrických testov pri ich vyhodnocovaní. Pri environmentálnych faktoroch sme sledovali, ako sa menia hodnoty obsahu humusu z hl'adiska využitia krajiny (kosená lúka, xerotermná lúka bez pol'nohospodárskej funkcie, les). Z hl'adiska ekologických faktorov, ktoré vplývajú na obsah humusu v pôdnych vzorkách, sme sledovali nadmorskú výšku, sklon a tvar reliéfu, sezónu (jeseň, jar), klimatické pomery (zrážky) vo vybraných lokalitách.

\section{Materiál a metódy}

Miesta odberov pôdnych vzoriek boli lokalizované v Kremnických a Štiavnických vrchoch (mapa 1). Kremnické a Štiavnické vrchy sú sopečné pohoria (Lukniš, red. 1972), ktoré sa nachádzajú na strednom Slovensku. Ide o čast' provincie Západné Karpaty, subprovincia Vnútorné Západné Karpaty, sú súčastou Slovenského stredohoria. Reliéf týchto pohorí modelovali aj eróznodenudačné procesy, ktoré ovplyvnili celkový ich charakter. Všetky lokality odberov vzoriek boli situované v Banskobystrickom kraji. Na každej lokalite bola vyčlenená plocha $(5 \times 5 \mathrm{~m})$ a následnej $\mathrm{v}$ nej bol realizovaný odber pôdnych vzoriek na 10 rôznych miestach počas rokov 2011 - 2014. Lokality odberu pôdnych vzoriek boli začlenené do troch výškových stupňov (Mazúr, red. 1980, Hrnčiarová, red. 2002) podl'a nadmorskej výšky (stupeň podhorský, horský, vyšší horský). Prehl'ad o klimatických podmienkach pre miesta odberu pôdnych vzoriek (P1-P10) sme získali prostredníctvom Slovenského hydrometeorologického ústavu (SHMÚ) z meteorologických staníc (Banská Štiavnica, Kremnické Bane, Žiar nad Hronom). Získané údaje sú len orientačné z dôvodu exponovanosti reliéfu, polohy a najmä rozdielov v nadmorskej výške. Miesta odberu pôdnych vzoriek boli nasledovné: vzorky P1-P3 v obci Ihráč (meteorologická stanica Žiar nad Hronom), vzorka P4 v obci Lúčky (meteorologická stanica Kremnické Bane), vzorky P5 - P10 v obci Ilija (meteorologická stanica Banská Štiavnica). Analyzované vzorky pôdy boli odobraté vo forme otvorených sond (do híbky $1 \mathrm{~m}$ ), na jeseň roku 2011, 2012, 2013 a na jar 2012, 2013 a 2014 (Hudec, Feszterová, 2015). Otvorená sonda slúžila na charakteristiku pôdy, pôdneho profilu a jeho híbky, stratigrafie a morfologických znakov. Základné charakteristiky lokalít sú uvedené v tab.1.

Pôdne vzorky boli odobrané z 3 hlavných pôdnych typov (andozem, kambizem, fluvizem) zo zvolených horizontov. Odobrané pôdne vzorky sa vysušili na vzduchu pri izbovej teplote a preosiali sa cez sito (oká s priemerom 0,125 mm, jemnozem II). 
Mapa 1: Miesta odberov pôdnych vzoriek podl'a využitia krajiny (zmiešaný les, xerotermná lúka, kosená lúka)

Map 1: Localization of monitoring places of soil samples according to the land use (mixed forest, xerothermic meadow, mown meadow)

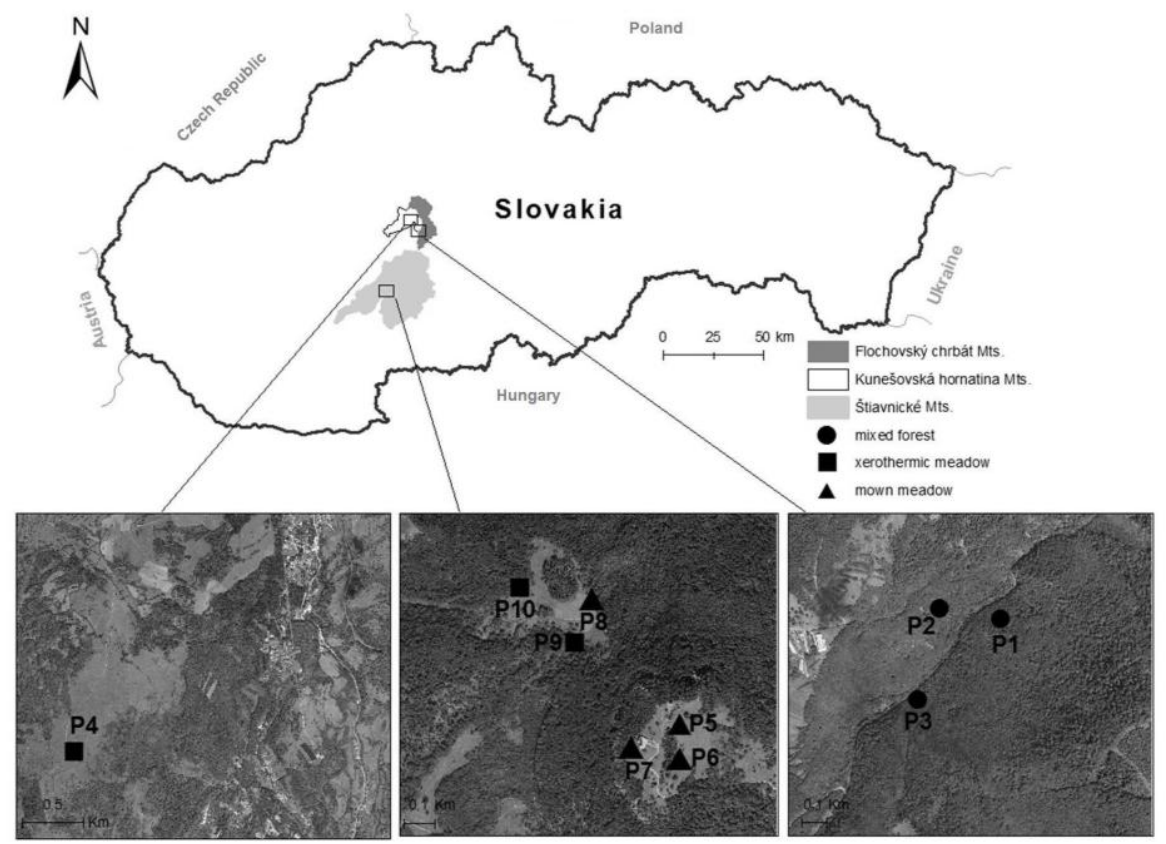

Vzorky boli analyzované štandardnými postupmi. Obsah celkového organického uhlíka (TOC) sme stanovili oxidometrickou metódou podla Ťjurina v modifikácii Nikitina podl'a Orlova a Grišinu (1981) a z jeho množstva sme vypočítali obsah humusu (Humus $=\mathrm{TOC}^{*} 1,724$ ).

$\mathrm{Na}$ posúdenie vplyvu environmentálnych faktorov na obsah pôdneho humusu sme použili dvojfaktorovú analýzu rozptylu hodnôt s interakciami na úrovni faktora lokalita a sezóna, lokalita a pôdny typ na hladine významnosti $\alpha=$ 0,05 (ANOVA). Pre zistenie kontrastov hodnôt pôdneho humusu vznikajúceho v procese humifikácie sme použili Tukey HSD - test. Testovanie kontrastov bolo realizované na úrovni faktorov využitie krajiny (kosená a xerotermná lúka, les) a lokalita a tiež na úrovni faktorov lokalita a pôdny typ na hladine významnosti $\alpha=0,05$. Dvojfaktorová analýza rozptylu bez interakcií na hladine významnosti $\alpha=0,05$ bola využitá aj na posúdenie vplyvu sklonu a odtokových pomerov na obsah humusu v pôde. 
Tab. 1: Charakteristika lokalít odberu pôdnych vzoriek $\mathrm{v}$ Kremnických a v Štiavnických vrchoch

Table 1: Characteristics of monitoring places in Kremnické and Štiavnické Mts.

\begin{tabular}{|c|c|c|c|c|c|c|c|c|c|c|}
\hline 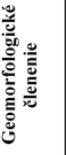 & & 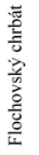 & & 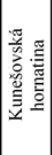 & \multicolumn{6}{|c|}{ 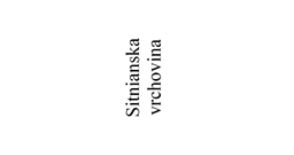 } \\
\hline 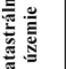 & \multicolumn{3}{|c|}{ 芭 } & 意 & \multicolumn{6}{|c|}{ 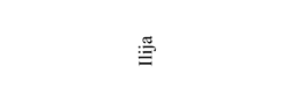 } \\
\hline 善 & 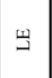 & $\stackrel{\uplus}{\exists}$ & $\underline{\Psi}$ & $\vec{x}$ & \lrcorner & - & \lrcorner & - & $\vec{x}$ & $\vec{x}$ \\
\hline 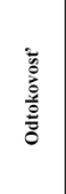 & 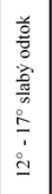 & 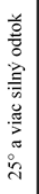 & 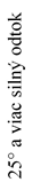 & 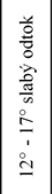 & 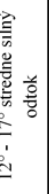 & 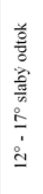 & 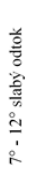 & 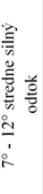 & 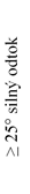 & 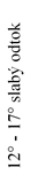 \\
\hline 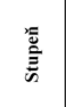 & 窝 & 窝 & 竞 & 䆓 & 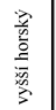 & 䆓 & 窨 & 容 & 童 & 竞 \\
\hline 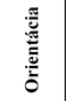 & $\geq$ & $\infty$ & $\geq$ & - & $\geq$ & $\geq$ & - & $>$ & $\cong$ & $\geq$ \\
\hline $\begin{array}{l}\frac{\pi}{\frac{\pi}{0}} \\
\stackrel{0}{\circ}\end{array}$ & 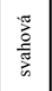 & 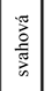 & 5 & 暮 & 荡 & 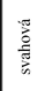 & 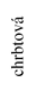 & 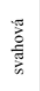 & 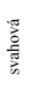 & 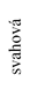 \\
\hline$\frac{1}{3}$ & 范 & $\begin{array}{l}\infty \\
:\end{array}$ & है & 专 & $\stackrel{2}{\delta}$ & 吉 & ஃू & $\bar{\sigma}$ & $\bar{\infty}$ & ஃั \\
\hline 象竞 & $\bar{\Sigma}$ & $\approx$ & $\cong$ & 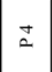 & $\cong$ & $\stackrel{0}{\circ}$ & $\hat{\imath}$ & $\stackrel{\infty}{\simeq}$ & $\hat{2}$ & $\stackrel{\circ}{2}$ \\
\hline
\end{tabular}

Legenda:
$\mathrm{XL}=$ xerotermná lúka
$\mathrm{J}=$ juh
$\mathrm{JV}=$ juhovýchod
SZ = severozápad
$\mathrm{LE}=$ les
$\mathrm{Z}=$ západ
$\mathrm{JZ}=$ juhozápad
$\mathrm{L}=$ kosená lúka
$\mathrm{V}=$ východ $\quad \mathrm{SV}=$ severovýchod 
Erózia materiálu na základe odtokových pomerov (slabý odtok, stredne slabý odtok, silný odtok, stredne silný odtok) bola posudzovaná v interakcii so sezónou pre konkrétne typy využitia krajiny (kosená lúka, xerotermná lúka bez pol'nohospodárskej funkcie, les) na hladine významnosti $\alpha=0,05$ (F-test, ANOVA). Využitím Tukey HSD - testu sme testovali kontrasty medzi hodnotami obsahu humusu na úrovni faktora erózia materiálu na hladine významnosti $\alpha=$ 0,05 . Získané výsledky sa vyhodnotili použitím štatistického softwaru STATISTICA na hladine významnosti $\alpha=0,05$.

\section{VÝSLEDKY A DISKUSIA}

Priemerné hodnoty obsahu humusu v pôde sledovaných foriem využitia krajiny sú spracované v tab. 2. Biotop lúky a pasienky nížinné a podhorské zahŕňal kosenú lúku, biotop mezofilné pasienky a spásané lúky zahŕn̆al pasienok a xerotermnú lúku bez pol'nohospodárskej funkcie a biotop bukové a jedl'ovobukové lesy kvetnaté lesy zahíňal les (Stanová, Valachovič, red. 2002). Najnižšie priemerné obsahy boli zistené na pasienkoch, ktoré boli intenzívne spásané ovcami. Naopak najvyššie priemerné hodnoty boli zistené v pôde lesa, kde zdrojom pôdnej organickej hmoty boli zvyšky opadanky. Naše dosiahnuté hodnoty humusu v pôde lesa súhlasia s výsledkami Uquetan et al. (2017). Aj podl'a Rusu et al. (2013) je obsah humusu vyšší v lese, ako v pôde trávnych porastov. Lesný ekosystém poskytuje značné množstvo organických prímesí, ktoré sú dôležité pre akumulačné procesy pôdy. Opadanka každoročne obnovuje príjem organických látok, ktoré sú neustále ukladané do vrchnej vrstvy pôdy s rôznou rýchlostou a intenzitou rozkladných procesov v závislosti od oblasti (Rusu et al., 2013). Ako uvádzajú Turrión, Schneider a Gallardo (2009), svoj vplyv na hodnoty obsahu humusu v pôde lesa má tiež pôdotvorný substrát.

Tab. 2: Priemerné hodnoty \pm SD humusu (\%) pôdneho profilu foriem využitia krajiny

Table 2: Average values \pm SD humus (\%) soil profile of landuse

\begin{tabular}{|l|c|c|c|c|c|c|}
\hline \multirow{2}{*}{$\begin{array}{l}\text { Sezóna / } \\
\text { Využitie } \\
\text { územia }\end{array}$} & $\mathbf{2 0 1 1}$ & \multicolumn{2}{|c|}{$\mathbf{2 0 1 2}$} & \multicolumn{2}{c|}{$\mathbf{2 0 1 3}$} & $\mathbf{2 0 1 4}$ \\
\cline { 2 - 7 } & Jeseň & Jar & Jeseň & Jar & Jeseň & Jar \\
\hline Kosená lúka & $3,75 \pm 3,27$ & $4,28 \pm 4,00$ & $4,75 \pm 4,69$ & $4,55 \pm 4,19$ & $5,28 \pm 4,44$ & $5,16 \pm 4,11$ \\
\hline Pasienok & $4,22 \pm 3,50$ & $3,41 \pm 2,53$ & $2,84 \pm 2,48$ & $2,89 \pm 1,73$ & $2,95 \pm 1,39$ & $3,34 \pm 2,14$ \\
\hline $\begin{array}{l}\text { Xerotermná } \\
\begin{array}{l}\text { lúka bez } \\
\text { pol'nohosp. } \\
\text { funkcie }\end{array}\end{array}$ & $10,11 \pm 8,05$ & $6,33 \pm 3,95$ & $8,78 \pm 6,80$ & $8,96 \pm 5,15$ & $6,24 \pm 3,60$ & $7,51 \pm 5,80$ \\
\hline Les & $10,44 \pm 4,43$ & $9,25 \pm 5,41$ & $7,04 \pm 4,64$ & $8,70 \pm 4,49$ & $8,53 \pm 3,10$ & $9,49 \pm 3,80$ \\
\hline
\end{tabular}


Štatistickým spracovaním dát s využitím jednofaktorovej analýzy rozptylu (ANOVA) od faktoru využitia krajiny sme zistili štatisticky významné rozdiely medzi hodnotami obsahu humusu v pôde pod rôznymi typmi foriem využitia zeme $(\mathrm{F}=20,756 ; \mathrm{p}=0,000)$. Na posúdenie kontrastov medzi obsahmi humusu v pôdach s rôznym využitím krajiny sme využili Tukey HSD - test. Medzi obsahmi humusu v pôde s rozdielnym využitím krajiny sme nezistili štatisticky významné rozdiely medzi xerotermnou lúkou bez pol’nohospodárskej funkcie a lesom $(\mathrm{p}=0,383)$ a ani medzi lúkou a pasienkom $(\mathrm{p}=0,093)$ na hladine významnosti $\alpha=0,05$ (tab. 3).

Tab. 3: Testovanie kontrastu obsahu humusu úrovní faktora využitia krajiny (Tukey HSD - test)

Table 3: Testing of the humus content contrasts on the factor location of land use (Tukey's HSD test)

\begin{tabular}{|l|c|c|c|c|}
\hline \multicolumn{1}{|c|}{ Využitie územia } & $\begin{array}{c}\text { Xerotermná } \\
\text { lúka bez } \\
\text { pol'nohosp. } \\
\text { funkcie }\end{array}$ & $\begin{array}{c}\text { Kosená } \\
\text { lúka }\end{array}$ & Pasienok & Les \\
\hline $\begin{array}{l}\text { Xerotermná lúka bez } \\
\text { pol'nohosp. funkcie }\end{array}$ & & 0,000 & 0,000 & 0,383 \\
\hline Kosená lúka & & & 0,093 & 0,000 \\
\hline Pasienok & & & & 0,000 \\
\hline Les & & & & \\
\hline
\end{tabular}

$\mathrm{p}<0,05$

Pre názornost' je na grafe 1 znázornená diferencia hodnôt obsahu humusu v pôdach s rozdielnym využitím krajiny.

Graf 1: Variabilita hodnôt obsahu humusu v pôde s rozdielnym využitím krajiny Graph 1: Variability of the humus content values in soil with different landuse

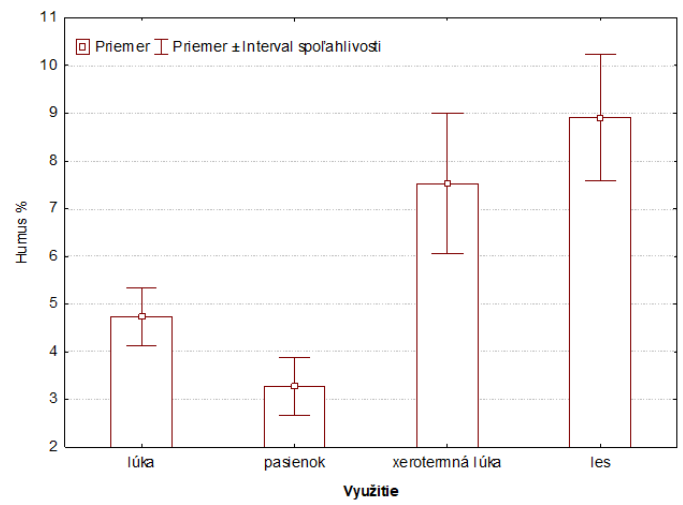


Najvyšší obsah humusu bol zistený v pôdnych vzorkách odobraných z lesa, čo nekorešponduje s tvrdením Muya a Mutsotsa (2008), ktorí zistili vyšší obsah celkového organického uhlíka $\mathrm{v}$ pôde prirodzených lúk, v porovnaní $\mathrm{s}$ hodnotami v pôde lesa, ale súhlasí s dosiahnutými výsledkami Uquetana et al. (2017). Podl'a Islamu a Weila (2000) úroveň celkového organického uhlíka v pôde má tendenciu byt' vyššia $\mathrm{v}$ zalesnených a lúčnych lokalitách, ale variabilita je príliš vysoká pre štatistickú významnost'. Vysoká variabilita hodnôt humusu vpôde lesa je pravdepodobne ovplyvnená prísunom pôdnej organickej hmoty prostredníctvom lesnej opadanky. Dôvodom vysokej variability hodnôt môže byt' aj pôdny typ, klimatické pomery, ale aj typ lesa (Bedrna, 2010). Vysoké hodnoty obsahov celkového organického uhlíka a percentá humusu vyplývajú podla Čurlíka a Šurinu (1998) z prekorenenia horizontov a zvýšeného množstva pôdnych mikroorganizmov. V prípade xerotermnej lúky bez pol'nohospodárskej funkcie je prísun čerstvých organických látok $\mathrm{v}$ priebehu celého roka zabezpečený odumretými zvyškami rastlín.

Najmenšia diferencia hodnôt obsahu humusu medzi jednotlivými sezónami bola zaznamenaná v pôde, ktorá sa využívala ako pasienok. Prísun čerstvej organickej hmoty vo forme exkrementov do pôdy ovplyvnilo pravidelné spásanie ovcami. Sezónne výkyvy obsahu humusu boli pre všetky lokality minimálne (tab. 4).

Tab. 4: Priemerné hodnoty \pm SD humusu [\%] v sezónach odberu pôdnych vzoriek Table 4: Average values \pm SD humus [\%] in seasons of soil sampling

\begin{tabular}{|c|c|c|c|c|c|c|}
\hline Sezóna & Jeseň 2011 & Jar 2012 & Jeseň 2012 & Jar 2013 & Jeseň 2013 & Jar 2014 \\
\hline Humus & $5,58 \pm 5,24$ & $5,06 \pm 4,40$ & $5,24 \pm 5,06$ & $5,39 \pm 4,60$ & $5,45 \pm 4,09$ & $5,80 \pm 4,58$ \\
\hline
\end{tabular}

Štatistickým spracovaním nameraných údajov s využitím dvojfaktorovej analýzy rozptylu s interakciami na úrovni faktora lokality a sezóny sme nezistili štatisticky významný vplyv sezóny na obsah humusu $(\mathrm{F}=0,443 ; \mathrm{p}=0,818)$. Zistili sme štatisticky významný vplyv lokality na obsah humusu v pôde $(F=4,627 ; p=$ $0,010)$ na hladine významnosti $\alpha=0,05$. Testovaním vzájomnej interakcie faktorov lokality a sezóny sme zistili, že ich interakcia na obsah humusu v pôde nie je štatisticky významná (tab. 5).

Štatisticky významný rozdiel medzi sezónami nebol zistený pravdepodobne z dôvodu diferenciácie pôdnych typov, ako aj z analýzy údajov pre všetky formy využitia zeme. Rozdiely v obsahu humusu neboli zistené ani medzi sezónami odberu pôdnych vzoriek pre dané klimatické lokality. Štatisticky významný rozdiel sme zistili len medzi lokalitami Žiar nad Hronom a Banská Štiavnica $(\mathrm{p}=0,005)$ na hladine významnosti $\alpha=0,05$ (tab. 6). 
Tab. 5: Analýza rozptylu hodnôt obsahu humusu s interakciami v závislosti od lokality a sezóny odberu pôdnych vzoriek

Table 5: Analysis of variance of the humus content values with interaction depending on the locality and season of soil sampling

\begin{tabular}{|c|c|c|c|c|c|}
\hline & SS & $\begin{array}{c}\text { Stupeň } \\
\text { vol'nosti }\end{array}$ & MS & F & p \\
\hline Lokalita & 213,372 & 2 & 106,686 & 4,627 & 0,010 \\
\hline Sezóna & 51,091 & 5 & 10,218 & 0,443 & 0,818 \\
\hline Lokalita*Sezóna & 230,387 & 10 & 23,039 & 0,999 & 0,444 \\
\hline
\end{tabular}

$\mathrm{p}<0,05 ; \mathrm{SS}=$ súčet štvorcov odchýlok; MS = priemerný štvorec odchýlok; $\mathrm{F}=$ hodnota testovacieho kritéria, $\mathrm{p}=$ hodnota pravdepodobnosti

Tab. 6: Testovanie kontrastov obsahu humusu úrovní faktora lokality meteorologickej stanice (Tukey HSD-test)

Table 6: Testing of the humus content contrasts on the factor location of the weather station (Tukey's HSD test)

\begin{tabular}{|c|c|c|c|}
\hline Lokalita & Žiar nad Hronom & Kremnické Bane & Banská Štiavnica \\
\hline Žiar nad Hronom & & 0,159 & 0,005 \\
\hline Kremnické Bane & & & 0,596 \\
\hline Banská Štiavnica & & & \\
\hline
\end{tabular}
$\mathrm{p}<0,05$

Vývoj obsahu humusu v pôde jednotlivých lokalít a v sledovaných sezónach je zobrazený na grafe 2 .

Graf 2: Vývoj obsahu humusu v pôdach v sezónach a v lokalitách Graph 2: Trend of the humus content in soils in seasons and localities

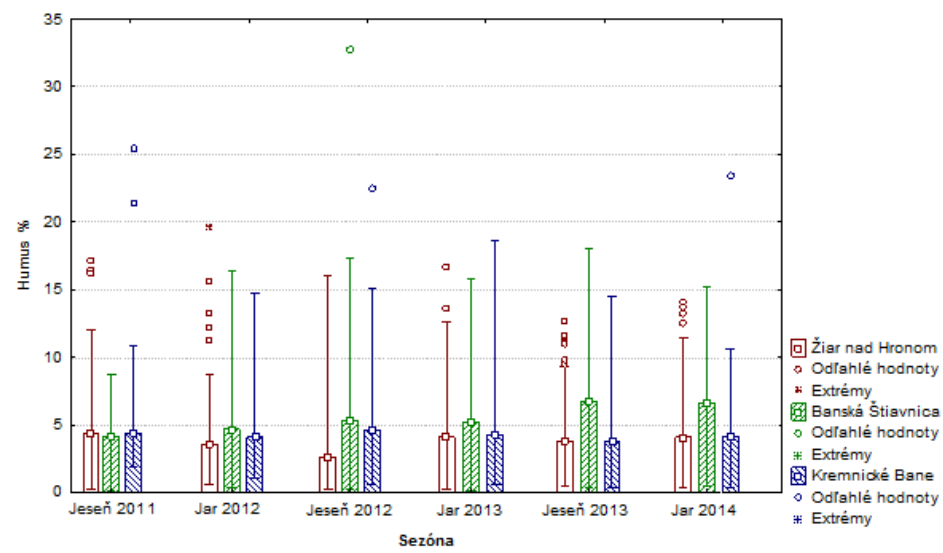


Najmenšie rozdiely $\mathrm{v}$ obsahu humusu medzi jednotlivými sezónami boli zistené v lokalite Žiar nad Hronom. Na tejto lokalite boli zaznamenané aj najmenšie priemerné hodnoty obsahu humusu i napriek tomu, že množstvo snehovej pokrývky a suma úhrnu zrážok bola najmenšia medzi jednotlivými obdobiami odberu pôdnych vzoriek (graf 3). Vyššie množstvo úhrnu zrážok a výška snehovej pokrývky môže ovplyvnit' odnos pôdy pri erózii a zároveň proces humifikácie. Najnižšie obsahy humusu pravdepodobne neovplyvnili jednotlivé klimatické premenné samostatne, ale aj v spoločnej súčinnosti, ked’že priemerné teploty boli pre všetky lokality porovnatel'né na hladine významnosti $\alpha=0,05\left(\chi^{2}=\right.$ $1,750 ; \mathrm{p}=0,417)$. Podl'a Burkeho et al. (1989) obsah organického uhlíka sa zvyšuje s množstvom zrážok, obsahom ílu a znižuje s teplotou. Oblasti vysokých pohorí sa vyznačujú pomalou mineralizáciou a vysokým obsahom humusu v dôsledku nedostatku kyslíka (Sobocká, 2007).

Graf 3: Suma úhrnu zrážok v sezónach a v loklitách (SHMÚ, 2014)

Graph 3: Values of total precipitation in seasons and localities (SHMÚ, 2014)

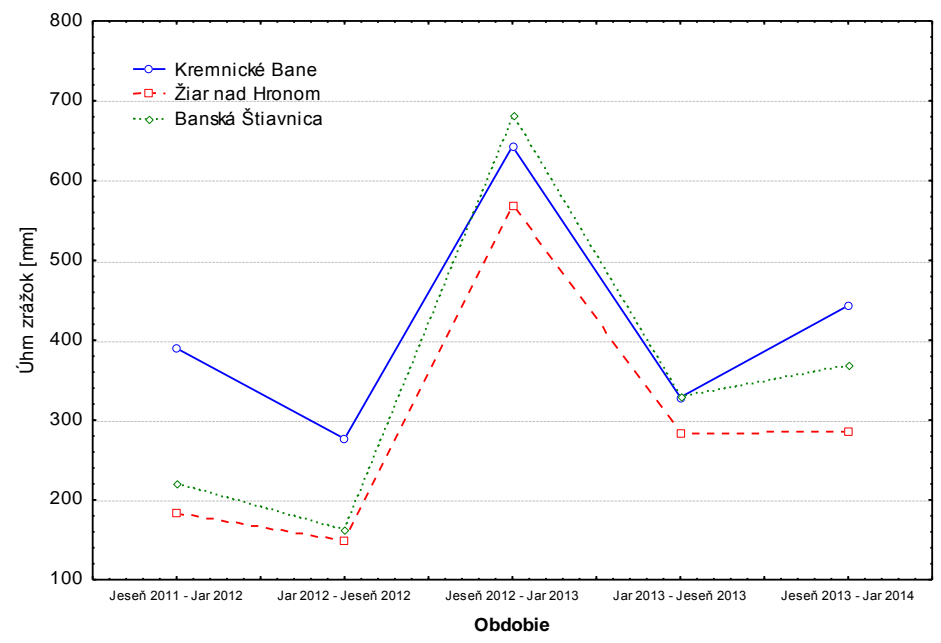

Rozdiel medzi lokalitami bol pravdepodobne spôsobený vel'kou diferenciáciou pôdnych typov a využitím krajiny vo vybraných lokalitách (Žiar nad Hronom, Banská Štiavnica). V lokalite Banská Štiavnica bolo zaznamenaných najviac pôdnych profilov s pôdnym typom andozem, ktorý sa vyznačuje vysokým obsahom humusu. Na tejto lokalite boli zaznamenané najvyššie priemerné obsahy humusu v pôde. Podl'a Barančíkovej (2005) disponujú andozeme na trvalých trávnatých porastoch vysokým obsahom organickej hmoty. Jones et al. (2004) udávajú ako hlavné faktory ovplyvňujúce obsah pôdnej organickej hmoty klimatické pomery, materskú horninu, pôdny pokryv, vegetáciu a nadmorskú 
výšku. Štatistickým spracovaním dát sme potvrdili vplyv klimatických podmienok $(\mathrm{F}=4,627 ; \mathrm{p}=0,010)$ a nadmorskej výšky $(\mathrm{F}=28,312 ; \mathrm{p}=0,000)$ na hladine významnosti $\alpha=0,05$.

Hodnoty obsahu humusu boli štatisticky posudzované tiež na úrovni faktora využitia krajiny a pôdneho typu vo vzájomnej interakcii. Štatistické testovanie bolo realizované pre pôdny typ andozem, fluvizem a kambizem. Zistili sme štatisticky významný rozdiel v obsahu pôdneho humusu medzi sledovanými pôdnymi typmi $(\mathrm{F}=94,685 ; \mathrm{p}=0,000)$ pre $\mathrm{p}<0,05$. Vplyv faktora lokality na obsah humusu v pôde pre pôdny typ andozem, fluvizem a kambizem, ktoré boli identifikované na všetkých klimatických lokalitách, nebol zistený $(F=0,731 ; p=0,393$ - tab. 7). Pre všetky pôdne typy bol rozdiel v hodnotách pôdneho humusu medzi lokalitami štatisticky významný, čo potvrdilo aj štatistické testovanie dát $(\mathrm{F}=4,627 ; \mathrm{p}=$ $0,010)$ na hladine významnosti $\alpha=0,05$.

Tab. 7: Analýza rozptylu hodnôt obsahu humusu v závislosti od pôdneho typu a lokality s interakciami

Table 7: Analysis of variance of the humus content values, depending on the soil type and location with interaction

\begin{tabular}{|l|r|l|r|r|c|}
\hline & \multicolumn{1}{|c|}{ SS } & $\begin{array}{c}\text { Stupeň } \\
\text { vol'nosti }\end{array}$ & MS & F & p \\
\hline Pôdny typ & 1510,897 & 1 & 1510,897 & 94,685 & 0,000 \\
\hline Lokalita & 11,667 & 1 & 11,667 & 0,731 & 0,393 \\
\hline Pôdny typ*Lokalita & 279,214 & 3 & 93,071 & 5,833 & 0,001 \\
\hline
\end{tabular}

$\mathrm{p}<0,05 ; \mathrm{SS}=$ súčet štvorcov odchýlok; MS = priemerný štvorec odchýlok; $\mathrm{F}=$ hodnota testovacieho kritéria, $\mathrm{p}=$ hodnota pravdepodobnosti

$\mathrm{Z}$ výsledkov uvedených $\mathrm{v}$ tab. 8 vidíme, že pre testovacie kritérium sklon terénu a erózie pôdy je $\mathrm{p}$ - hodnota rovná $0,000(\mathrm{p}=0,000)$ na hladine významnosti $\alpha=0,05$, čo znamená, že hodnoty obsahu humusu v pôde štatisticky významne závisia od sklonu terénu a erózie pôdy. V práci Koleda et al. (2012) pri testovaní zmien obsahu humusu v procese humifikácie vjarnom a jesennom období v závislosti od horizontálnej, vertikálnej krivosti a sklonov bola zaznamenaná štatisticky významná zmena v prípade svahu $17^{\circ}-25^{\circ}$ so silnou pôdnou eróziou $(\mathrm{p}=0,046 ; \mathrm{p}<0,05)$, v pôdnom type andozem $\mathrm{v}$ lesnom ekosystéme Kremnických vrchov. $\mathrm{V}$ týchto odberných miestach došlo $\mathrm{v}$ jarnom období $\mathrm{k}$ poklesu obsahu humusu až o 32,8 \%. Toto tvrdenie súhlasí s našimi výsledkami. Rozdiely medzi niektorými sezónami sú z dôvodu odlišných medzisezónnych klimatických podmienok. Stockfisch et al. (1999) zistili vyššie hodnoty uhlíka v pôde na jeseň ako na jar. Uvedené rozdiely si vysvetl'ujú tým, že na jeseň boli zapracované zvyšky predplodiny (korene), kým na jar boli zvyšky už čiastočne rozložené a bola vytvorená nová rovnováha $\mathrm{v}$ pôdnej organickej hmote. 
Tab. 8: Výsledná tabul'ka dvojfaktorovej analýzy rozptylu obsahu humusu bez interakcií v závislosti od sklonu terénu a odnosu pôdy pri erózii

Table 8: Two-factor analysis of variance of the humus content without interaction depending on the relief slope and soil erosion

\begin{tabular}{|c|c|c|c|c|c|}
\hline & SS & $\begin{array}{c}\text { Stupeň } \\
\text { Vol'nosti }\end{array}$ & MS & F & $\mathbf{p}$ \\
\hline Sklon & 423,133 & 4 & 105,783 & 17,248 & 0,000 \\
\hline Pôdna erózia & 330,166 & 3 & 110,055 & 17,945 & 0,000 \\
\hline
\end{tabular}

$\mathrm{p}<0,05 ; \mathrm{SS}=$ súčet štvorcov odchýlok; MS = priemerný štvorec odchýlok; $\mathrm{F}=$ hodnota testovacieho kritéria, $\mathrm{p}=$ hodnota pravdepodobnosti

Štatistickým posudzovaním interakcie environmentálneho a ekologického faktora na proces humifikácie sme zistili vplyv odnosu pôdy pri erózii $(\mathrm{F}=13,864 ; \mathrm{p}=0,000)$ na hodnoty obsahu humusu v pôde pre $\mathrm{p}<0,05$ (tab. 9).

Tab. 9: Výsledná tabul'ka dvojfaktorovej analýzy rozptylu obsahu humusu s interakciami pre všetky typy využitia krajiny v závislosti od odnosu pôdy pri erózii a sezóny odberu pôdnych vzoriek

Table 9: Two-factor analysis of variance of the humus content with interaction for all types of landuse, depending on the soil erosion and soil sampling season

\begin{tabular}{|l|c|c|c|c|c|}
\hline & SS & $\begin{array}{c}\text { Stupeň } \\
\text { vol'nosti }\end{array}$ & MS & F & p \\
\hline Pôdna erózia & 298,446 & 3 & 99,482 & 13,864 & 0,000 \\
\hline Sezóna & 19,389 & 5 & 3,878 & 0,540 & 0,746 \\
\hline Pôdna erózia*Sezóna & 128,157 & 15 & 8,544 & 1,191 & 0,276 \\
\hline
\end{tabular}

$\mathrm{p}<0,05 ; \mathrm{SS}=$ súčet štvorcov odchýlok; MS = priemerný štvorec odchýlok; $\mathrm{F}=$ hodnota testovacieho kritéria, $\mathrm{p}=$ hodnota pravdepodobnosti

Vplyv odnosu pôdy pri erózii a sezóny s interakciami bol štatisticky posudzovaný pre jednotlivé typy využitia krajiny (kosená lúka, xerotermná lúka bez pol'nohospodárskej funkcie, les - tab. 10). Pre pasienok analýza nebola realizovaná z dôvodu, že všetky miesta odberu pôdnych vzoriek na pasienkov boli zaradené v rámci intenzity pôdnej erózie ako slabé $\left(7^{\circ}-12^{\circ}\right.$ a $\left.12^{\circ}-17^{\circ}\right)$. Zistili sme, že odnos pôdy eróziou mal štatisticky významný vplyv na hodnoty obsahu humusu v pôde kosenej lúky $(\mathrm{p}=0,000 ; \mathrm{p}<0,05)$ a v pôde lesa $(\mathrm{p}=0,001 ; \mathrm{p}<$ $0,05)$. Odnos pôdy pri erózii nemal štatisticky významný vplyv na hodnoty humusu v pôde xerotermnej lúky bez pol'nohospodárskej funkcie $(\mathrm{p}=0,549 ; \mathrm{p}<0,05)$. Jedným z dôvodov bol pravidelný prísunu organickej hmoty do pôdy vo forme opadanky. 
Tab. 10: Výsledná tabul'ka dvojfaktorovej analýzy rozptylu obsahu humusu s interakciami pre konkrétne typy využitia krajiny v závislosti od odnosu pôdy pri erózii a sezóny odberu pôdnych vzoriek

Table 10: Two-factor analysis of variance of the humus content with interaction for specific types of land-use, depending on the soil erosion and soil sampling season

\begin{tabular}{|c|c|c|c|c|c|}
\hline Kosená lúka & SS & $\begin{array}{c}\text { Stupeň } \\
\text { vol'nosti }\end{array}$ & MS & $\mathbf{F}$ & $\mathbf{p}$ \\
\hline Pôdna erózia & 344,485 & 2 & 172,243 & 32,010 & 0,000 \\
\hline Sezóna & 49,587 & 5 & 9,917 & 1,843 & 0,106 \\
\hline Pôdna erózia *Sezóna & 77,591 & 10 & 7,759 & 1,442 & 0,164 \\
\hline $\begin{array}{c}\text { Xerotermná lúka bez } \\
\text { pol'nohospodárskej } \\
\text { funkcie }\end{array}$ & SS & $\begin{array}{c}\text { Stupeň } \\
\text { vol'nosti }\end{array}$ & MS & $\mathbf{F}$ & $\mathbf{p}$ \\
\hline Pôdna erózia & 4,587 & 1 & 4,587 & 0,364 & 0,549 \\
\hline Sezóna & 6,942 & 2 & 3,471 & 0,275 & 0,761 \\
\hline Pôdna erózia*Sezóna & 38,180 & 7 & 5,454 & 0,432 & 0,877 \\
\hline Les & SS & $\begin{array}{c}\text { Stupeň } \\
\text { vol'nosti }\end{array}$ & MS & $\mathbf{F}$ & $\mathbf{p}$ \\
\hline Pôdna erózia & 78,396 & 1 & 78,396 & 13,718 & 0,001 \\
\hline Sezóna & 15,158 & 5 & 3,032 & 0,531 & 0,752 \\
\hline Pôdna erózia*Sezóna & 24,915 & 5 & 4,983 & 0,872 & 0,509 \\
\hline
\end{tabular}

$\mathrm{p}<0,05 ; \mathrm{SS}=$ súčet štvorcov odchýlok; MS = priemerný štvorec odchýlok; F = hodnota testovacieho kritéria, $\mathrm{p}=$ hodnota pravdepodobnosti

Pre zistenie kontrastov medzi jednotlivými kategóriami pôdnej erodovanosti sme použili Tukey HSD - test. Zistili sme štatisticky významné rozdiely v kategóriách pôdnej erodovanosti medzi kategóriou slabá a ostatnými kategóriami (tab. 11) na hladine významnosti $\alpha=0,05$.

Tab. 11: Testovanie kontrastu obsahu humusu v pôde úrovní kategórií erodovanosti pôd (Tukey HSD - test)

Table 11: Testing of the humus content contrasts on the factor level of the soil erodibility (Tukey's HSD test)

\begin{tabular}{|c|l|c|c|c|c|}
\hline & \multicolumn{1}{|c|}{ Kategórie erodovanosti } & $\{1\}$ & $\{2\}$ & $\{3\}$ & $\{4\}$ \\
\hline$\{1\}$ & Slabá & & 0,002 & 0,005 & 0,000 \\
\hline$\{2\}$ & Stredne slabá & & & 0,821 & 0,972 \\
\hline$\{3\}$ & Silná & & & & 0,446 \\
\hline$\{4\}$ & Stredne silná & & & & \\
\hline
\end{tabular}


Odnos pôdy pri erózii na svahu môžu ovplyvnit’ aj iné faktory prostredia ako orientácia svahu. Podl'a Koledu et al. (2012) orientácia reliéfu (expozícia) súvisí s d'alšími faktormi ako teplota, intenzita vetra a doba trvania slnečného svitu, ktoré vplývajú na danú lokalitu.

$\mathrm{Na}$ lokalitách so slabou eróziou pôdy (slabou eróziou pôdy) sme nezaznamenali výrazné rozdiely medzi priemernými hodnotami obsahu humusu (tab. 12) medzi sezónami odberu pôdnych vzoriek.

Tab. 12: Vývoj hodnôt obsahu humusu \pm SD [\%] pre rôzne kategórie erodovanosti pôd $\mathrm{v}$ daných sezónach

Table 12: Development of the humus content values \pm SD [\%] for different categories of soil erodibility in monitored seasons

\begin{tabular}{|l|c|c|c|c|c|c|}
\hline $\begin{array}{c}\text { Kategórie } \\
\text { erodovanosti }\end{array}$ & Jeseň 2011 & Jar 2012 & Jeseň 2012 & Jar 2013 & Jeseň 2013 & Jar 2014 \\
\hline Slabá & $5,23 \pm 5,60$ & $4,29 \pm 4,03$ & $4,14 \pm 4,58$ & $4,60 \pm 4,28$ & $4,54 \pm 3,71$ & $4,76 \pm 4,27$ \\
\hline Stredne slabá & $4,75 \pm 0,45$ & $7,11 \pm 5,08$ & $9,00 \pm 3,95$ & $10,96 \pm 2,30$ & $8,18 \pm 2,92$ & $8,81 \pm 4,08$ \\
\hline Silná & $10,18 \pm 3,73$ & $6,84 \pm 3,51$ & $6,02 \pm 3,61$ & $5,84 \pm 3,17$ & $6,28 \pm 2,77$ & $7,93 \pm 3,98$ \\
\hline Stredne silná & $4,91 \pm 2,74$ & $8,02 \pm 5,15$ & $12,79 \pm 10,36$ & $8,50 \pm 5,48$ & $8,93 \pm 5,74$ & $8,84 \pm 5,24$ \\
\hline
\end{tabular}

Na týchto lokalitách boli zaznamenané aj najnižšie priemerné obsahy humusu v porovnaní s obsahmi na lokalitách so stredne slabým až stredne silným odnosom pôdy pri erózii. Rozdielnost' $\mathrm{v}$ obsahoch potvrdzuje aj testovanie kontrastov prostredníctvom Tukey HSD - testu. Na lokalitách s vyšším faktorom erodovanosti dochádzalo $\mathrm{k}$ výraznej dynamike a distribúcii humusových látok, čo spôsobilo výrazné rozdiely v obsahu humusu medzi jednotlivými sezónami odberu pôdnych vzoriek.

\section{Záver}

Environmentálne problémy súvisiace $\mathrm{s}$ ochranou prírodných prvkov (ovzdušie, voda, pôda, biota, horninové prostredie) zdrojov a rizikovými faktormi (odpady, hluk, radón), racionálnym využívaním zdrojov energie, kolobehom látok a energie $\mathrm{v}$ prírode nie sú problémami neznámymi. Antropogénne činnosti podstatne môžu zvýšit dostupnost' živín v pôde, čo ovplyvňuje ekosystémové procesy a funkcie, najmä v ekosystémoch s obmedzenou výživou, ako sú trávne porasty. Špecifické vlastnosti nadobúda humus v oblasti kontaminovaných pôd. Fungovanie lúčneho a lesného ekosystému zahŕňa významné procesy, ovplyvňujúce kolobeh živín, cyklus vody, ako aj odbúravanie toxických látok. Najviac významným procesom prebiehajúcim v daných ekosystémoch je predovšetkým cyklus uhlíka prostredníctvom, ktorého dochádza k transformácii anorganického uhlíka na organický, ako aj procesy akumulácie uhlíka zahrňujúce 
sekvestráciu, humifikáciu a dekompozíciu, pričom dochádza k vytváraniu zásob uhlíka aj v hlbších vrstvách pôdy. Na udržanie, prípadné zvýšenie pôdnej úrodnosti je potrebné zachovanie rovnováhy medzi tvorbou humusu a jeho rozkladom. Zistili sme, že na proces humifikácie vplýva lokalita, pôdny typ, sklon reliéfu, sezóna, klíma, nadmorská výška, ale predovšetkým využitie pôdneho pokryvu. Štatistické testovanie environmentálnych a ekologických faktorov na obsah humusu v pôde predstavuje význam nástoj na zist’ovanie, či prevláda proces humifikácie a rastlinné zvyšky sú pevne viazané v humusových látkach a pre porast sú nevyužitel'né, alebo v prípade prevahy mineralizácie sa uvol'ňujú živiny, čím dochádza k ubúdaniu humusu, k zhoršeniu pôdnych vlastností a k zníženiu úrodnosti.

\section{Pod'akovanie}

Príspevok bol spracovaný v rámci projektu KEGA č. 044UKF-4/2017 s názvom „Modernizácia výučby a interdisciplinárneho prístupu v rámci kategórie odpad a odpadové hospodárstvo ".

\section{Literatúra}

ALEKSANDROWICZ-TRZCIŃSKA, M. 2005. Stan mikoryz sosny zwyczajnej w uprawie założonej na gruncie porolnym. In Sylwan. 2005, vol. 149, no. 2, pp. 42-49.

BARANČÍKOVÁ, G. 2005. Vývoj pôdnej organickej hmoty na vybraných pôdnych typoch trvalých trávnatých porastov a orných pôd v priebehu monitoringu. In Sobocká, J. (ed.). Štvrté pôdoznalecké dni na Slovensku, zborník z vedeckej konferencie pôdoznalcov SR. Bratislava: VÚPOP, 2005. ISBN 80-89128-18-1, s. 7-13.

BEDRNA, Z. 2010. Les a pásmovitost' pôd. In Acta Geographica Universitatis Comenianae. 2010. vol. 5, no. 1, pp. 53-62.

BURKE, I. C. - YONKER, C. M. - PARTON, W. J. - COLE, C. V. - SCHIMEL, D. S. - FLACH, K. 1989. Texture, Climate, and Cultivation Effects on Soil Organic Matter Content in U.S. Grassland Soils. In Soil Science Society of America Journal. 1989, vol. 53, no. 3, pp. 800-805.

ČURLÍK, J. - ŠURINA, B. 1998. Príručka terénneho prieskumu a mapovania pôd. Bratislava: Výskumný ústav pôdnej úrodnosti, 1998. 134 s. ISBN 8085361-37-X.

FRATERRIGO, J. M. - TURNER, M. G. - PEARSON, S. M. 2003. The effect of prior land use on the spatial distribution of soil chemical properties in southern Appalachian forests. In 18th Annual general meeting. Alberta, Canada, 2003.

HRNČIAROVÁ, T. (red.). 2002. Atlas krajiny Slovenskej republiky. Bratislava, Banská Bystrica: MŽP SR, SAŽP, 2002. 107 s. ISBN 80-88833-27-2. 
HUDEC, M. - FESZTEROVÁ, M. 2015. Humifikácia na neovulkanitoch Kremnických a Śtiavnických vrchov. Nitra: UKF v Nitre, 2015. 145 s. ISBN 978-80-5580-866-6.

ISLAM, K. R. - WEIL, R. R. 2000. Land use effects on soil quality in a tropical forest ecosystem of Bangladesh. In Agriculture, Ecosystems and Environment. 2000, vol. 79, pp. 9-16.

JONES, R. J. A. - HIEDERER, R. - RUSCO, E. - LOVELAND, P. J. MONTANERELLA, L. 2004. The map of organic carbon in topsoils in Europe. Version 1.2, European Soil Bureau Research Report, no. 17, 26 p.

KOLEDA, P. - HUDEC, M. - FESZTEROVÁ, M. 2012. GIS a jeho využitie na polohovú charakteristiku pri sledovaní procesu humifikácie $\mathrm{v}$ pôde Kremnických vrchov. In Nováková, M., Sviček, M. (eds). Environmentálne indexy a indikátory ako nástroje analýzy a hodnotenia stavov a procesov $v$ krajine. 2012. ISBN 978-80-89128-97-6, s. 105-113.

LUKNIS, M. red. 1972. Slovensko. Príroda 2. Bratislava: Obzor, 1972. 917 s.

MAZÚR, E. 1980. Hypsografické stupne 1 : 500 000. In Mazúr, E. red. Atlas SSR. 1980. s. 38-39.

MUYA, E. M. - MUTSOTSO, B. 2008. Characteristics of Below-Ground Biodiversity Sites in Kenya: Their Constraints, Interventions and Emerging Issues. In Tropical and Subtropical Agroecosystems. 2008, pp. 991-1003.

ORLOV, D. S. - GRIŠINA, L. A. 1981. Praktikum po chemiji gumusa. Moskva: Izdatel'stvo Moskovskovo uniresiteta, 1981.272 p.

RUSU, E. - PATRICHE, C. V. - ROSCA, B. - PITICAR, M. 2013. The Influence of Land Use on some Soil Parameters in the Câmpulung Moldovenesc Depresion. In Soil Forming Factors and Processes from the Temperate Zone. 2013, vol. 12, no. 2, pp. 89-95.

SOBOCKÁ, J. 2007. Detekcia a cielená regulácia pôdneho organického uhlíka z hl'adiska očakávaných účinkov klimatickej zmeny. In Sobocká, J. (ed.). Funkcia uhlika v pôde pri ochrane pôdy a produkcii biomasy, zborník vedeckých a diskusných príspevkov z vedeckej rozpravy XXX. valného zhromaždenia členov SAPV. Nitra: Agentúra Slovenskej akadémie pol'nohospodárskych vied, 2007. č. 56. ISBN 978-80-89162-29-1, s. 35-44.

STOCKFISCH, N. - FORSTREUTER, T. - EHLERS, W. 1999. Ploughing effects on soil organic mater after twenty years of conservation tillage in Lower Saxony Germany. In Soil and Tillage Research. vol. 52, pp. 91-101.

STANOVÁ, V. - VALACHOVIČ, M. (eds.). 2002. Katalóg biotopov Slovenska. [online] Bratislava: DAPHNE - Inštitút aplikovanej ekológie, 225 p. [cit. 2018-09-20]. Dostupné na internete: http://www.sopsr.sk/dokumenty/Katalogbiotopov-SK.pdf

TURRIÓN, M. B. - SCHNEIDER, K. - GALLARDO, J. F. 2009. Carbon accumulation in Umbrisols under Quercus pyrenaica forests: Effects of bedrock and annual precipitation. In Catena. 2009, vol. 79, no. 1, pp. 1-8. 
UQUETAN U. I. - EZE E. B. - UTTAH C. - OBI E. O. - EGOR A. O. - OSANG J. E. 2017. Evaluation of Soil Quality in Relation to Landuse Effect in Akamkpa, Cross River State - Nigeria. In Applied Ecology and Environmental Sciences. 2017, vol. 5, no. 2, pp. 35-42. DOI: 10.12691/aees-5-2-2.

\section{EVALUATON OF HUMUS CONTENT IN SOIL BASED ON ENVIRONMENTAL AND ECOLOGICAL FACTORS IN SELECTED AREAS OF CENTRAL SLOVAKIA}

\section{Summary}

The content of soil organic matter in the soil depends on the environmental and ecological relations. These relations have an impact positive and negative effect on the humification process in the soil. The process of humification is influenced by location, soil type, slope relief, season of the year, climate, altitude, but by using soil cover. The aim of our study was summarized the impact of the land use and vegetation cover on the soil properties of different soil types in the volcanic mountains of the Slovak Republic (Kremnické vrchy Mts. and Śtiavnické vrchy Mts.). The main process was to sum up the impact of seasons (autumn, spring) and ecosystems (mixed forest, mown and xerothermic meadows) on the differences in the values of total organic carbon (TOC) soil types from 2011 to 2014. The content of total organic carbon in soil was not influenced by the method of land use despite reporting diverse values of TOC. Published results show present significance of differences. The TOC content was not statistically influenced by seasons. The content was higher in natural grassland and natural forest, but the variability of results did not show statistical significance. The content of humus in soil was influenced by erosion of soil base on drainage conditions in all types of land - use. The exception was xerothermic meadow with a high supply of fresh organic matter that provides regular supply of organic matter. The article describes the possibilities of using parametric tests that evaluated the humus content base on environmental and ecological factors. To the impact of environmental factors on humus content in soil was used two - factor analysis of variance values with the interaction between the season and location factors, location and soil type at a significance level of $\alpha=0.05$ (ANOVA). We used Tukey's HSD test to determine the values of soil humus generated at humification process. The contrast testing was performed at the level of land - use (mown and xerothermic meadows, pasture, forest) and location factors and also at the factors of location and soil type, at the level of significance of $\alpha=0.05$. The two - factor analysis of variance without interaction at the level of significance $\alpha=$ 0.05 was used to assess the influence of slope and drainage at the humus content in the soil. Erosion of material that was influenced by drainage conditions was assessed in interaction with all seasons for a specific type of land use at the level of 
significance $\alpha=0.05$ (F - test, ANOVA). It was performed Tukey's HSD test the contrasts between the values of humus drainage factor at the level of significance $\alpha$ $=0.05$ was tested. The results were evaluated by using the software STATISTICA at the level of significance $\alpha=0.05$. The various statistical methods were used to assess the impact of environmental and ecological characteristics on selected soil characteristics. It is important to apply statistical methods in environmental monitoring, where huge amount of data and search for mutual connections are being processed.

\section{doc. Ing. Melánia Feszterová, PhD.}

Fakulta prírodných vied

Univerzita Konštantína Filozofa v Nitre

Trieda A. Hlinku 1, 94974 Nitra, Slovensko

E-mail: mfeszterova@ukf.sk

\section{PaedDr. Michal Hudec, PhD.}

Piaristické gymnázium sv. Jozefa Kalazanského

Piaristická 6, 94901 Nitra, Slovensko

E-mail: michal.hudec81@gmail.com 